\title{
Ubiquity of heterotrophic diazotrophs in marine microbial mats
}

\author{
Julie B. Olson ${ }^{1, *}$, R. Wayne Litaker ${ }^{2}$, Hans W. Paerl ${ }^{1, * *}$ \\ 'Institute of Marine Sciences, University of North Carolina at Chapel Hill, Morehead City, North Carolina 28557, USA \\ ${ }^{2}$ Program in Molecular Biology and Biotechnology, University of North Carolina at Chapel Hill, Chapel Hill, \\ North Carolina 27599, USA
}

\begin{abstract}
Cyanobacteria are a dominant structural component of $\mathrm{N}_{2}$-fixing microbial mats in diverse marine ecosystems. As a result, much of the measured $\mathrm{N}_{2}$ fixation activity has been attributed to the cyanobacterial component. Until recently, the contribution of heterotrophic $\mathrm{N}_{2}$ fixers has received much less attention. In this study, the presence, diversity, and ubiquity of heterotrophic $\mathrm{N}_{2}$ fixers were investigated in 3 cyanobacteria (Microcoleus)-dominated, intertidal microbial mats obtained from Tomales Bay, California, Sippewissett Salt Marsh, Massachusetts, and Bird Shoal, North Carolina. Using PCR techniques, a diverse array of heretofore uncharacterized heterotrophic nifH (gene encoding the Fe-protein subunit of nitrogenase) sequences were found in these geographically disparate microbial mats, suggesting that heterotrophic diazotrophs may play a larger role in $\mathrm{N}_{2}$ fixation dynamics than previously thought. Phylogenetically similar heterotrophic diazotrophic sequences were obtained from the 3 sites, potentially indicating that similar heterotrophic $\mathrm{N}_{2}$-fixing communities are responsible for this process at diverse locations.
\end{abstract}

KEY WORDS: Microbial mat $\cdot$ Heterotrophic bacteria $\cdot \mathrm{N}_{2}$ fixation $\cdot$ Cyanobacteria

\section{INTRODUCTION}

$\mathrm{N}_{2}$ fixation in marine systems has primarily been attributed to cyanobacteria (Dugdale et al. 1961, Fogg 1982, Carpenter \& Capone 1983, Capone et al. 1997). More recently, the potential contribution of heterotrophic bacterial diazotrophs has attracted attention as numerous and diverse eubacterial nifH (gene that encodes the highly conserved Fe-protein subunit of nitrogenase) gene sequences were detected in the marine environment (Zehr et al. 1995, Steppe et al. 1996). The discovery that Microcoleus chthonoplastes, a ubiquitous and often dominant cyanobacterial species in $\mathrm{N}_{2}$-fixing microbial mats, does not have the genetic potential (structural nif genes) for $\mathrm{N}_{2}$ fixation (Steppe et al. 1996) also pointed to heterotrophic bacteria as possibly playing a far more significant role in this process than previously thought. It has been inferred from several studies that marine $\mathrm{N}_{2}$-fixing

- Present address: Harbor Branch Oceanographic Institution, Fort Pierce, Florida 34946, USA

'Addressee for correspondence. E-mail: hans_paerl@unc.edu bacteria, under conditions favorable for diazotrophy, may contribute significantly to $\mathrm{N}$ requirements (Paerl \& Prufert 1987, Paerl \& Carlton 1988, Shieh et al. 1989). Additionally, a number of studies based on culturing have indicated that bacterial $\mathrm{N}_{2}$ fixers are present in diverse marine habitats (Maruyama et al. 1970, Kawai \& Sugahara 1971, Wynn-Williams \& Rhodes 1974, Guerinot \& Colwell 1985), yet only now are we beginning to understand the distribution, prevalence, and diversity of these organisms.

Microbial mats are among the most dynamic, N-limited habitats in the marine environment. These laterally compressed ecosystems host a spectrum of microenvironments oriented along steep vertical $\mathrm{O}_{2}$ and redox gradients (Cohen et al. 1984, Bebout et al. 1987, Paerl et al. 1989) and often thrive in $\mathrm{N}$-deplete coastal or estuarine environments (e.g. mudflats, lagoons, reefs, salt marshes, and mangroves; Cohen et al. 1984). Mats are composed of metabolically diverse microorganisms, including cyanobacteria, diatoms, and bacteria, that compete for available nutrients (e.g. $\mathrm{N}, \mathrm{P}, \mathrm{Fe}$, and $\mathrm{C}$ ) and environmental niches. Previous studies have shown that a large diazotrophic commu- 
nity exists in these mats (Bebout et al, 1987, Tibbles \& Rawlings 1994, Paerl et al. 1996), most likely as a result of the selective advantage conferred by their ability to utilize $\mathrm{N}_{2}$ in the face of intense competition for existing combined $\mathrm{N}$ sources.

Although the genes for nitrogenase are highly conserved (Postgate 1982), the niff gene in particular has been shown to provide useful taxonomic information (Ben-Porath \& Zehr 1994, Zehr et al. 1995, Steppe et al. 1996). A combination of isolation, cultivation, and molecular characterization was used to determine the presence, diversity, and ubiquity of heterotrophic $\mathrm{N}_{2}$ fixers in cyanobacteria-dominated microbial mats obtained from geographically diverse sites. Internal nifH primers were designed from the diazotrophic isolates to examine the potential impact these bacteria may have on $\mathrm{N}_{2}$ fixation rates. The results suggest that heterotrophic diazotrophs are ubiquitous in microbial mat environments and that numerous, phylogenetically similar, and thus far uncharacterized, $\mathrm{N}_{2}$ fixers are present at the sites.

\section{MATERIALS AND METHODS}

Study sites. Three intertidal marine microbial mat systems were selected as sampling sites for this study. All have been shown to exhibit high rates of $\mathrm{N}_{2}$ fixation, although seasonal differences in $N_{2}$ fixation potential and mat development (i.e. thickness) have been documented (e.g. Valiela \& Teal 1979, Joye \& Paerl 1994, Pinckney et al. 1995, Paerl et al. 1996). The Tomales Bay, California, mat, located in the Walker Creek drainage basin near the mouth of Tomales Bay $\left(38^{\circ} 13^{\prime} \mathrm{N}, 122^{\circ} 80^{\prime} \mathrm{W}\right)$, is composed of fine muds and silts and exhibits strong vertical biogeochemical zonation. The 2 remaining mats, located at Bird Shoal, North Carolina $\left(34^{\circ} 40^{\prime} \mathrm{N}, 76^{\circ} 42^{\prime} \mathrm{W}\right)$, and Sippewissett

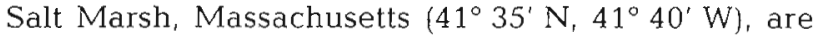
composed primarily of quartz sand grains. Both mats are well developed $(0.2$ to $1.0 \mathrm{~cm}$ thick $)$ and their microbial biomass is dominated by cyanobacteria (primarily Oscillatoria spp., Lyngbya spp., and Microcoleus spp.)

Sample collection. Microbial mat samples were collected from the 3 sites during 1994 to 1997 . Vertical stabs taken throughout the mats were inoculated into various semi-solid $\mathrm{N}$-free media including unamended seawater (SW), artificial seawater (SA-N; Tibbles \& Rawlings 1994) with mannitol, lactate (L), and 'free lunch' (FL; Currin et al. 1990) agarose tubes (see Table 1). Semi-solid media were prepared using from $0.3 \% \mathrm{w} / \mathrm{v}$ agar (purified agar; Fisher Scientific, Pittsburgh, PA) to $0.1 \% \mathrm{w} / \mathrm{v}$ agarose (SeaKem LE; FMC Bioproducts, Rockland, ME) as solidifying agents ac- cording to the recipe. Mat samples were also inoculated into liquid media and streaked onto agar plates $(15 \times 100 \mathrm{~mm})$ prepared with 1 to $1.5 \% \mathrm{w} / \mathrm{v}$ agar. SW with mannitol and yeast extract (SW-MY), FL, and SW were the preferred solid media while SA-N and FL were the primary liquid culture media. Stabs and streaks were conducted using sterile, disposable $10 \mu l$ inoculating loops at the field site or were performed immediately upon the arrival of a $5 \times 5 \mathrm{~cm}$ square of mat at the laboratory. If the mat was transported to the laboratory prior to sampling, only the central, undisturbed region of the square was used for sampling.

Isolation of $\mathbf{N}_{\mathbf{2}}$-fixing bacteria. All incubations were conducted between 20 and $25^{\circ} \mathrm{C}$. After growth was noted on the plates (incubations ranged from 1 to $10 \mathrm{~d}$ ), individual colonies were streaked onto fresh plates of the same medium. This procedure was repeated until a uniform colonial morphology was seen and a single cellular morphology microscopically verified. In semi-solid media, $10 \mu l$ aliquots of actively-growing bacteria, as determined by visible turbidity, were transferred to agar plates of the same media and individual colonies were transferred until a single isolate was obtained. SW-MY agar plates and SA-N semi-solid tubes were the preferred media for isolating marine diazotrophs.

Nitrogenase activity. Nitrogenase activity was determined using the acetylene reduction assay (Hardy et al. 1968). Each isolate was inoculated into a $13 \mathrm{ml}$ glass, screw-capped test tube containing $6 \mathrm{ml}$ of semisolid ( $0.1 \%$ agarose) SA-N medium with mannitol. All samples were incubated for $24 \mathrm{~h}$ at room temperature. The screw caps were removed and replaced with sterile, $13 \mathrm{~mm}$, rubber serum stoppers with sleeves. Sleeves were turned down over the test tubes and $1.5 \mathrm{ml}$ of freshly made acetylene, generated from $\mathrm{CaC}_{2}$, was injected into the headspace of each tube. Cultures were incubated for an additional $24 \mathrm{~h}$ at room temperature. Following incubation, $2 \mathrm{ml}$ samples of headspace gas were removed and injected into evacuated vials. A Leap Technologies CTC A200SE autosampler was used to inject $0.225 \mathrm{ml}$ volume per sample for analysis into a Shimadzu GC $9 \mathrm{~A}$ gas chromatograph (GC) equipped with a flame ionization detector and a $2 \mathrm{~m}$ Poropak-T stainless steel column maintained at $80^{\circ} \mathrm{C}$. High purity $\mathrm{N}_{2}$ was used as the carrier gas.

DNA extraction, PCR, and sequencing. Cells were taken from solid media and suspended in $100 \mu \mathrm{l}$ of a sterile 5\% Chelex 100 (100 to 200 mesh sodium form resin; Bio-Rad Laboratories, Richmond, CA) in distilled water solution in a $0.65 \mathrm{ml}$ sterile microcentrifuge tube. DNA extraction was achieved by incubating the tubes at $70^{\circ} \mathrm{C}$ for several (2 to 3 ) hours with periodic vigorous vortexing (every $30 \mathrm{~min}$ ). Amplification of the nifH gene was performed using the parameters and primers outlined in Zehr \& McReynolds (1989). PCR products 
were gel purified and cloned into $\mathrm{pCR}^{\otimes} 2.1$ Vector (Invitrogen, San Diego, CA). Sequencing was done by the UNC-CH Automated DNA Sequencing Facility on a Model 373A DNA Sequencer (Applied Biosystems) using the Taq DyeDeoxy ${ }^{T M}$ Terminator Cycle Sequencing Kit (Applied Biosystems).

Phylogenetic analysis. nifH sequences were aligned and translated using GCG Seqlab Software (1996) prior to being checked manually. The Protein Distance (Dayhoff PAM Matrix) and Neighbor (Neighborjoining) programs in Phylip (Felsenstein 1995) were used to construct phylogenetic distance-based reconstructions. PAUP (phylogenetic analysis using parsimony) 3.1 (Swofford 1991) was used to generate phylogenetic estimates using parsimony from the sequence data.

Environmental DNA extraction. Approximately $250 \mathrm{mg}$ of each microbial mat sample (collected on all sampling dates and stored at $-20^{\circ} \mathrm{C}$ until use) was used for DNA extraction with the Dneasy Plant Mini Kit (Qiagen Inc., Chatsworth, CA). The resulting raw extractions were eluted over QIAamp Tissue Kit (Qiagen Inc.) columns twice. Spectrophotometric analysis of the extractions at 260:280 $\mathrm{nm}$ determined that the eluates were clean enough for PCR amplification (ratios of 1.7 to 1.9 ) and that there was sufficient DNA in each sample.
Internal primer design and implementation. Three sets of non-degenerate internal primers were designed from conserved regions within the nifH gene sequences obtained from the mat isolates. Each primer incorporated a minimum of 5 character differences from the consensus sequence to a maximum of 14 differences. All primers were at least 17 oligonucleotides in length and were shown to be highly specific for the desired region within the nifH gene. Lower case nucleotides within the primers indicate sites of variance from the consensus sequence.

(1) sf primer set (279 bp amplification product): designed using conserved regions from isolates sf24, bs-sa2, tb5-24, tb13-32, tb2-31, bs12-2, bs1-9, tb med wh, and bs4-64. Primer 1: 5'-CacgAattggcAtCGCg-3'; Primer 2: 5'-CctacAcactaAgatgc-3'.

(2) tb primer set (167 bp amplification product): designed from isolates bs-sa4, tb $\mathrm{mg} 10$, tb $\mathrm{mg} 15$, and tb14-24. Primer 1: 5'-GTAtTactcActGGtTACa-3'; Primer 2: 5'.GTCACCCAatACaTCGTAa-3'.

(3) wc primer set (174 bp amplification product): designed from isolates wc2-3sm, wc1-2sm, wc2-3lg, and wc1-2 8.3. Primer 1: 5'-gGGttCcGTTGAAGAtcTtG-3'; Primer 2: 5'-aACaAAgTctAagTCaTCaTCG-3'.

The primers were synthesized by the UNC-CH Lineberger Oligonucleotide Facility and diluted in sterile $\mathrm{dH}_{2} \mathrm{O}$ to a final concentration of approximately

Table 1. Media recipes used in the inoculation of microbial mat samples in this study

\begin{tabular}{|c|c|c|}
\hline Medium name & Consistencies & Recipe \\
\hline Free lunch $(\mathrm{FL})$ & $\begin{array}{l}\text { Solid, } \\
\text { liquid }\end{array}$ & $\begin{array}{l}23.4 \mathrm{~g} \mathrm{NaCl}, 0.75 \mathrm{~g} \mathrm{KCl}, 7.0 \mathrm{~g} \mathrm{MgSO} \\
0.015 \mathrm{~g} \mathrm{KH}_{2} \mathrm{PO}_{4}, 1.0 \mathrm{~g} \text { mannitol, } 1.0 \mathrm{~g} \text { yeast extract, } 1.0 \mathrm{~g} \text { peptone, } 1 \mathrm{ml} \text { trace } \\
\text { metal solution } \cdot 1 \text { I distilled } \mathrm{H}_{2} \mathrm{O}, 10 \mathrm{~g} \text { agar for plates, } 3 \mathrm{~g} \text { agar for semi-solid tubes }\end{array}$ \\
\hline Lactate (L) & $\begin{array}{l}\text { Solid, } \\
\text { semi-solid, } \\
\text { liquid }\end{array}$ & $\begin{array}{l}25 \mathrm{~g} \mathrm{NaCl}, 0.5 \mathrm{~g} \mathrm{NH}_{4} \mathrm{Cl}_{1} 0.2 \mathrm{~g} \mathrm{MgSO}_{4} \cdot 7 \mathrm{H}_{2} \mathrm{O}, 0.1 \mathrm{~g} \mathrm{CaCl}_{2} \cdot 2 \mathrm{H}_{2} \mathrm{O}, 1.0 \mathrm{~g} \mathrm{~K}_{2} \mathrm{HPO}_{4} \text {, } \\
0.1 \mathrm{~g} \mathrm{FeSO} \cdot 7 \mathrm{H}_{2} \mathrm{O}, 0.5 \mathrm{~g} \mathrm{Na}_{2} \mathrm{SO}_{4}, 1.0 \mathrm{~g} \text { yeast extract, } 4.6 \mathrm{ml} 60 \% \text { sodium lactate } \\
\text { syrup or } 4.0 \mathrm{~g} \text { powdered form, } 1 \mathrm{l} \text { distilled } \mathrm{H}_{2} \mathrm{O}, 10 \mathrm{~g} \text { agar for plates, } 3 \mathrm{~g} \text { agar for } \\
\text { semi-solid tubes }\end{array}$ \\
\hline $\begin{array}{l}\text { Artificial } \\
\text { seawater } \\
(\mathrm{SA}-\mathrm{N})\end{array}$ & $\begin{array}{l}\text { Solid, } \\
\text { semi-solid, } \\
\text { liquid }\end{array}$ & $\begin{array}{l}\text { (1) } 24.95 \mathrm{~g} \mathrm{NaCl}_{1} 3.0 \mathrm{~g} \mathrm{MgSO} \cdot 7 \mathrm{H}_{2} \mathrm{O}, 2.0 \mathrm{~g} \mathrm{MgCl}_{2} \cdot 6 \mathrm{H}_{2} \mathrm{O}, 0.75 \mathrm{~g} \mathrm{KCl}, 0.12 \mathrm{~g} \\
\mathrm{CaCl}_{2} \cdot 2 \mathrm{H}_{2} \mathrm{O}, 6.0 \mathrm{~g} \text { Tris, } 0.001 \mathrm{~g} \text { disodium EDTA, } 1.0 \mathrm{ml} \text { trace metal solutiona, } \\
500 \mathrm{ml} \text { distilled } \mathrm{H}_{2} \mathrm{O} \text {, pH to } 7.8 \\
\text { (2) } 5.0 \mathrm{~g} \text { mannitol, glucose, or combination of mannitol and glucose, } 0.01 \mathrm{~g} \text { yeast } \\
\text { extract, } 400 \mathrm{ml} \text { distilled } \mathrm{H}_{2} \mathrm{O}, 10 \mathrm{~g} \text { agar or } 1 \mathrm{~g} \text { agarose added to this component } \\
\text { when desired } \\
\text { (3) } 0.8 \mathrm{~g} \mathrm{~K}_{2} \mathrm{HPO}_{4}, 0.2 \mathrm{~g} \mathrm{KH}_{2} \mathrm{PO}_{4}, 100 \mathrm{ml} \text { distilled } \mathrm{H}_{2} \mathrm{O} \text { Autoclave components (1), } \\
\text { (2) and (3) separately and combine when cool, } \mathrm{FeSO}_{4} \cdot 7 \mathrm{H}_{2} \mathrm{O} \text { added to final conc. } \\
\text { of } 0.015 \mathrm{~g} \mathrm{l}^{-1} \text { and } \mathrm{Na}_{2} \mathrm{MoO}_{4} \cdot 2 \mathrm{H}_{2} \mathrm{O} \text { to } 0.005 \mathrm{~g} \mathrm{l}^{-1}\end{array}$ \\
\hline $\begin{array}{l}\text { Seawater mannitol- } \\
\text { yeast (SW-MY) }\end{array}$ & Solid & $\begin{array}{l}8.0 \mathrm{~g} \text { mannitol, } 0.05 \mathrm{~g} \text { yeast extract, } 0.14 \mathrm{~g} \mathrm{NaNO}_{3}, 0.6 \mathrm{ml} \text { trace metal solution }{ }^{\mathrm{d}} \text {, } \\
1.0 \mathrm{ml} \text { phosphate solution }{ }^{\mathrm{b}}, 1 \mathrm{l} \text { filtered seawater, } 10 \mathrm{~g} \text { agar for plates }\end{array}$ \\
\hline Seawater (SW) & $\begin{array}{l}\text { Solid, } \\
\text { semi-solid }\end{array}$ & $1 \mathrm{l}$ filtered seawater, $10 \mathrm{~g}$ agar for plates, $3 \mathrm{~g}$ agar for semi-solid tubes \\
\hline \multicolumn{3}{|c|}{$\begin{array}{l}2.86 \mathrm{~g} \mathrm{H}_{3} \mathrm{BO}_{3}, 1.81 \mathrm{~g} \mathrm{MnCl}_{2} \cdot 4 \mathrm{H}_{2} \mathrm{O}, 0.22 \mathrm{~g} \mathrm{ZnSO}_{4} \cdot 7 \mathrm{H}_{2} \mathrm{O}, 0.39 \mathrm{~g} \mathrm{Na}_{2} \mathrm{MoO}_{4} \cdot 5 \mathrm{H}_{2} \mathrm{O}, 0.079 \mathrm{~g} \mathrm{CuSO}_{4} \cdot 5 \mathrm{H}_{2} \mathrm{O}, 0.049 \mathrm{~g} \mathrm{Co}^{\left.\mathrm{N} \mathrm{NO}_{3}\right)_{2}} \text {. } \\
6 \mathrm{H}_{2} \mathrm{O}, 0.32 \mathrm{~g} \mathrm{FeCl}_{3} \cdot 6 \mathrm{H}_{2} \mathrm{O}, 0.44 \mathrm{~g} \mathrm{Na}_{2} \mathrm{EDTA}_{1} 1000 \mathrm{ml} \text { distilled } \mathrm{H}_{2} \mathrm{O} \\
{ }^{5} \mathrm{O} .0 \mathrm{~g} \mathrm{Na \textrm {H } _ { 2 }} \mathrm{PO}_{4} \cdot \mathrm{H}_{2} \mathrm{O}, 1 \text { ld distilled } \mathrm{H}_{2} \mathrm{O}\end{array}$} \\
\hline
\end{tabular}




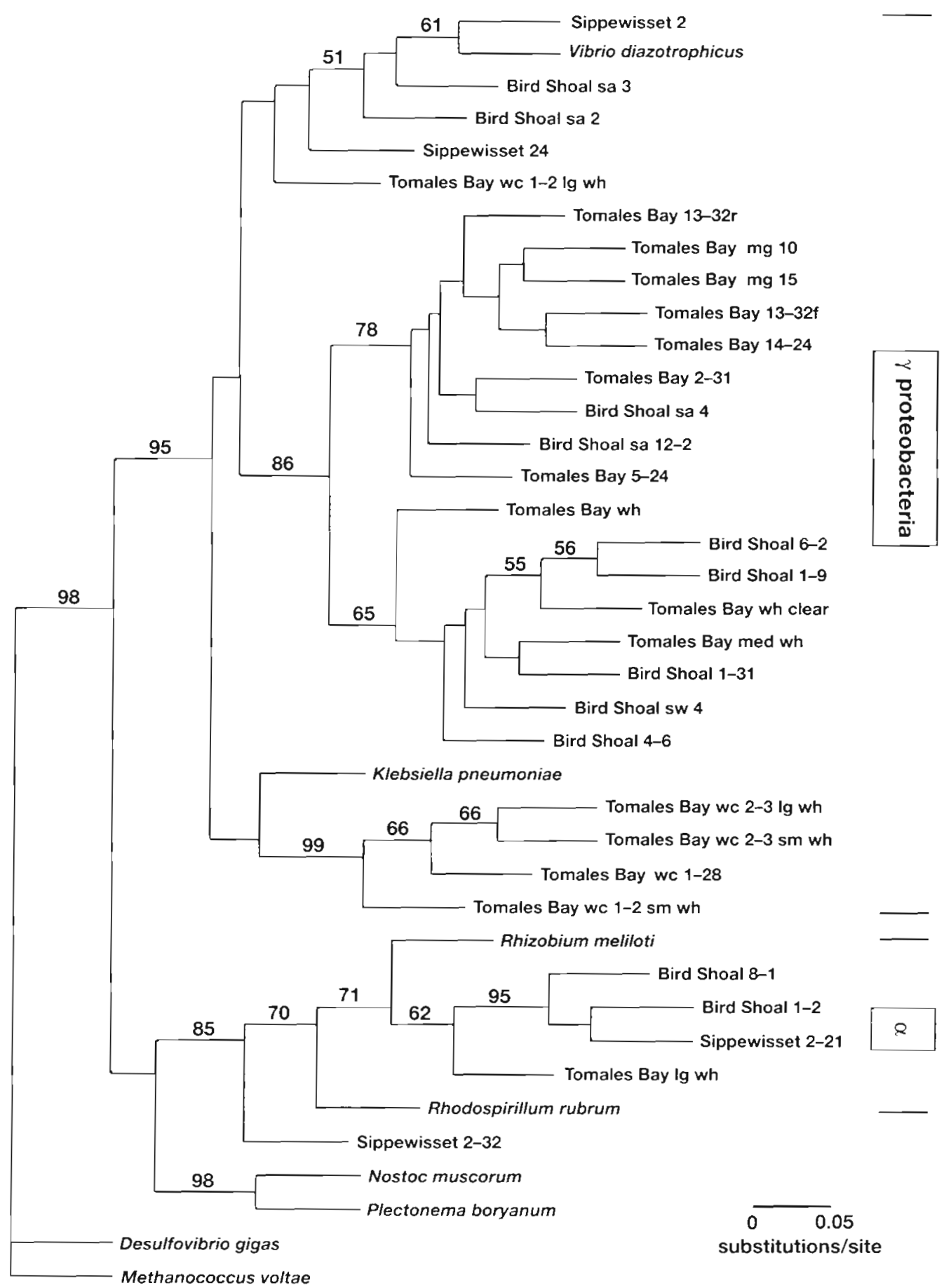

Fig. 1. Phylogenetic tree of translated nifH sequences. Distances were generated with Phylip's Protdist program and the tree was constructed using the Neighbor (neighbor-joining) program. The data were bootstrapped 1000 times, with bootstrap values greater than $50 \%$ shown above the branches leading to the corresponding node. Phylogenetic reconstructions with Phylip and PAUP (phylogenetic analysis using parsimony) demonstrated similar clade composition with only minor changes in branching order. As a result, only 1 phylogenetıc estimate is shown

$500 \mathrm{ng}$ primer $\mu \mathrm{l}^{-1}$. PCR conditions were as in Zehr \& McReynolds (1989), using 40 cycles and an annealing temperature of $45^{\circ} \mathrm{C}$. PCR optimization reactions were performed for the sf primer set using the conditions outlined above and the Opti-Prime ${ }^{\text {TM }}$ PCR Optimization kit (Stratagene, La Jolla, CA). 


\section{RESULTS}

The acetylene reduction assay was employed to verify the nitrogenase activity of each isolate. Because we were interested in examining an active community, the ability to express nitrogenase was a requirement for selection. As a result, diazotrophs that were not capable of $\mathrm{N}_{2}$ fixation under laboratory conditions were not studied further. Additionally, due to the isolation methods used, only those organisms that displayed some aerotolerance were obtained. Strict anaerobic diazotrophs could not be cultured and isolated effectively using the techniques and isolation procedures described previously. Even with these limitations, a diverse community of heterotrophic $\mathrm{N}_{2}$ fixers was obtained from the intertidal microbial mats.

Over 50 bacterial diazotrophs were isolated from the 3 sites throughout the study period and these displayed varying cellular and colonial morphologies. The majority of the isolates were short, ovoid-rods, but several long rods and coccoid species were noted. All were Gram-negative organisms requiring $\mathrm{NaCl}$ (data not shown), and most (>90\%) were motile, via either polar or peritrichous flagella. Thirty-one of the more than 50 heterotrophic isolates were found to have unique nifH gene sequences (Fig. 1, Table 2).

The purpose of designing primer sets specific for conserved regions within the isolates obtained was to determine if these cultured organisms were present in sufficient number to be detected at any or all of the microbial mat sites. Each of the environmental samples demonstrated significant nitrogenase activity (>0.5 nmol $\mathrm{C}_{2} \mathrm{H}_{2}[10 \mu \mathrm{l} \text { inoculum } \mathrm{h}]^{-1}$ ) at the time of collection, indicating the presence of an active diazotrophic community. Therefore, DNA extracts from these samples were expected to contain nifH gene fragments and amplification was obtained from all environmental mat samples using the degenerate nifH primers developed by Zehr \& McReynolds (1989). The extent of amplification was visually determined from the PCR products obtained. DNA from one of the isolates within the subset used to design each set was employed as a positive control for each amplification reaction. Negative controls consisted of a reagent blank (no DNA added) and DNA from isolates for which the primers were not designed (negative DNA control). No amplification was observed in any of the negative controls. Unlike the degenerate nifH primers, the internal primers demonstrated high specificity for the target region as only a single band of the appropriate size was observed for positive amplifications. Cloning and sequencing of a PCR product from each primer set indicated that the amplified bands contained partial nifH sequences.
Table 2. Genbank accession numbers for the isolates and reference species used in phylogenetic analyses

\begin{tabular}{|lc|}
\hline lsolate name & Genbank accession no. \\
\hline Tomales Bay wc 1-2 lg wh & U43442 \\
Tomales Bay wc 2-3 lg wh & U43443 \\
Tomales Bay wc 2-3 sm wh & U434444 \\
Tomales Bay wh clear & AF046827 \\
Bird Shoal sa 2 & AF046828 \\
Bird Shoal sw 4 & AF046829 \\
Bird Shoal 1-2 & AF046830 \\
Bird Shoal 1-9 & AF046831 \\
Bird Shoal 12-2 & AF046832 \\
Bird Shoal 1-31 & AF046833 \\
Bird Shoal 4-6 & AF046834 \\
Bird Shoal 6-2 & AF046835 \\
Bird Shoal 8-1 & AF046836 \\
Bird Shoal sa 3 & AF046837 \\
Bird Shoal sa 4 & AF046838 \\
Sippewissett 2-32 & AF046839 \\
Sippewissett 2-21 & AF046840 \\
Sippewissett 24 & AF046841 \\
Sippewissett 2 & AF046842 \\
Tomales Bay 13-32f & AF046843 \\
Tomales Bay 13-32r & AF046844 \\
Tomales Bay 14-24 & AF046845 \\
Tomales Bay 2-31 & AF046846 \\
Tomales Bay 5-24 & AF046847 \\
Tomales Bay lg wh & AF046848 \\
Tomales Bay mg 10 & AF046849 \\
Tomales Bay mg 15 & AF046850 \\
Tomales Bay wh & AF046851 \\
Tomales Bay med wh & AF046852 \\
Tomales Bay wc 1-28 & AF046853 \\
Tomales Bay wc 1-2 sm wh & AF046854 \\
Vibrio diazotrophicus & U23650 \\
Klebsiella pneumoniae & J01741 \\
Rhizobium meliloti & J01781 \\
Rhodospirillum rubrum & M33774 \\
Nostoc muscorum & U04054 \\
Plectonema boryanum & L15552 \\
Desulfovibrio gigas & U68183 \\
Methanococcus voltae & X03777 \\
\hline
\end{tabular}

Table 3 shows the results of amplification reactions using the internal primer sets with each of the mat DNA extractions. All of the samples exhibited nitrogenase activity using the acetylene reduction assay and provided a PCR amplification product with the degenerate nifH primers (Zehr \& McReynolds 1989). Amplification with at least one of the internal primer sets was obtained from 11 of the 12 environmental samples, demonstrating the presence of heterotrophic $\mathrm{N}_{2}$ fixers in the mats that were genetically similar to the isolates obtained. Samples collected during both winter and summer months showed amplification with the internal primers, indicating that heterotrophic diazotrophs are present in the mats throughout the year. The Bird Shoal and Sippewissett mats, the 2 sand-dominated systems, displayed more similar nifH amplification 
Table 3. nifH amplification results using the degenerate and newly designed partial gene internal primer sets with environmental microbial mat DNA samples. + = amplification product visually similar in intensity to product obtained using the degenerate nifH primers from Zehr \& McReynolds (1989); \pm = amplification product apparent but significantly less intense than product obtained with primers from Zehr \& McReynolds (1989); $-=$ no amplification product seen

\begin{tabular}{|lccccc}
\hline $\begin{array}{l}\text { Sample site } \\
\text { and date (mo/yr) }\end{array}$ & $\begin{array}{c}\text { nifH } \\
\text { degenerate } \\
\text { primers }\end{array}$ & $\begin{array}{c}\text { sf } \\
\text { set }\end{array}$ & $\begin{array}{c}\text { tb } \\
\text { primer } \\
\text { set }\end{array}$ & $\begin{array}{c}\text { wr } \\
\text { primer } \\
\text { set }\end{array}$ \\
\hline Bird Shoal 10/94 & + & \pm & + & \pm \\
Bird Shoal 2/95 & + & \pm & + & \pm \\
Bird Shoal 3/95 & + & - & + & - \\
Bird Shoal 9/95 & + & \pm & + & - \\
Bird Shoal 2/96 & + & - & - & + \\
Sippewissett 7/94 & + & - & + & - \\
Sippewissett 2/96 & + & \pm & + & \pm \\
Sippewissett 8/96 & + & \pm & + & \pm \\
Tomales Bay (WC) & $2 / 94$ & + & + & - & - \\
Tomales Bay 2/94 & + & - & - & - \\
Tomales Bay 5/95 & + & \pm & - & - \\
Tomales Bay 2/96 & + & - & - & + \\
\hline
\end{tabular}

profiles than that obtained from the silt-based Tomales Bay site (see Table 3). This difference is largely based on a lack of nifH amplification with Tomales Bay samples and may be a result of problems associated with DNA extraction from environmental samples. Even with this slight difference, the sequence similarity of the isolated diazotrophs from all 3 sites suggests that comparable diazotrophic communities may be present and responsible for the heterotrophic $\mathrm{N}_{2}$ fixation in these mats.

\section{DISCUSSION}

Diazotrophs exhibiting very similar nifH sequences were isolated from the 3 geographically diverse microbial mat sites. This indicates that either the diazotrophic communities at these sites are similar in composition, or that the culturing limitations associated with aquatic systems only permitted the growth and characterization of certain easily cultivated diazotrophic species. The isolates obtained demonstrated that marine microbial mats support a diverse assemblage of culturable heterotrophic $\mathrm{N}_{2}$ fixers. A number of the isolates may be microaerophilic, based on their phylogenetic placement near the nifH sequences of 2 microaerophilic (i.e. facultative anaerobes) reference species, Klebsiella pneumoniae and Vibrio diazotrophicus. Microaerophily may optimize the potential for $\mathrm{N}_{2}$ fixation in this dynamic, biogeochemically (i.e. $\mathrm{O}_{2}$ ) stratified system and microaerophiles may be an overlooked, but significant, component of the diazotrophic community. All isolates grew on media using mannitol as the primary carbon source. Mannitol and certain other media additions were shown to increase the aerotolerance of microaerophiles (Krieg \& Hoffman 1986). Additional growth factors, such as the production of mucilagenous outer coating noted for many of the isolates, may promote lower $\mathrm{O}_{2}$ concentrations around the cell by retarding the inward flow of $\mathrm{O}_{2}$, providing conditions favorable for $\mathrm{N}_{2}$ fixation (Bothe 1982).

A majority of the isolates were motile, suggesting that the organisms could migrate to environmentally suitable regions along biogeochemical gradients. Mat diazotrophs were obtained during both winter and summer, demonstrating that the potential for heterotrophic $\mathrm{N}_{2}$ fixation was present year-round and substantiating earlier suggestions based on rate measurements (Bebout et al. 1993, Paerl et al. 1996). Because it was recently determined that the dominant mat cyanobacterial genus Microcoleus does not possess the genes necessary for $\mathrm{N}_{2}$ fixation (Steppe et al. 1996), microheterotrophs may be larger contributors to this process than previously assumed (Bebout et al. 1987, 1993, Pinckney et al. 1995).

Comparisons of microbial phylogeny generated using either nifH or 16S rRNA gene sequences appear to be largely similar (Hennecke et al. 1985, Young 1992, Olson et al. unpubl.), indicating that tentative phylogenetic relationships of the unknown diazotrophic isolates may be determined by analysis of nifH sequences (Ueda et al. 1995, Zehr et al. 1995). All of the nifH sequences obtained appeared to cluster within 2 subgroups, the $\alpha$ and $\gamma$ proteobacteria (Woese 1987, Fig. 1). Five isolates clustered near Vibrio diazotrophicus, one of 8 reference organisms used for establishing phylogenetic relationships. This $\gamma$ proteobacterium was recognized as the first Vibrio sp. capable of $\mathrm{N}_{2}$ fixation, and has since been more fully characterized (Guerinot et al. 1982, Urdaci et al. 1988). Additional diazotrophic Vibrio species have been isolated from estuarine and oceanic environments (Guerinot et al. 1982, Guerinot \& Colwell 1985) and demonstrate a particularly strong affinity for surfaces, especially under nutrient-deficient conditions (Dawson et al. 1981). These requirements are consistent with the surface-rich, nutrient-limited habitat provided by microbial mats. Sequence analysis suggests that the closely clustered isolates are also $\gamma$ proteobacteria and may be Vibrio sp. or other closely related genera (e.g. Colwellia sp.). The $\gamma$ proteobacteria subgroup has been well characterized because it tends to be more amenable to laboratory culture than other subgroups (Woese et al. 1985, Holt et al. 1994). Several of the other isolates appear to cluster with Rhizobium meliloti and Rhodospirillum rubrum, both members of the $\alpha$ pro- 
teobacteria subgroup. This subgroup is particularly well adapted for establishing mutualistic relationships with other organisms (Woese 1987), potentially providing the necessary environmental conditions (e.g. low $\mathrm{O}_{2}$ concentration) for diazotrophy through consortial interactions (Paerl \& Pinckney 1996).

The extraction of DNA from environmental samples is also problematic, especially from sediment systems exhibiting significant polysaccharide and humic contamination (Tsai \& Olson 1992, Lovell \& Piceno 1994, Zhou et al. 1996, Jackson et al. 1997). Extraction procedures from such environmental samples typically do not provide high percentage (>90\%) DNA yields as differential lysis of cells (e.g. Gram-negative vs Grampositive cells), degradation or shearing of DNA, and binding of DNA to contaminating substances occurs. Thus, the limitations associated with DNA extraction techniques may have played a role in determining which of the samples demonstrated amplification with the internal nifH primer sets. Additionally, because the primer sets were designed solely from the isolated heterotrophic diazotrophs, anaerobic or cyanobacterial $\mathrm{N}_{2}$ fixers would not be detected with these primers but would likely be successfully amplified with the degenerate, but seemingly universal, nifH primers of Zehr \& McReynolds (1989).

In the absence of amplification with the internal nifH primer sets designed from the isolates, it could be conicluded that culture bias had permitted the growth and isolation of relatively rare but readily culturable diazotrophic species not necessarily well represented within the natural community. As a result, these organisms would be of little consequence to $\mathrm{N}_{2}$ fixation inputs. Alternatively, if the primers consistently detected these subgroups, then it could be inferred that the species isolated were at least partially representative of the diazotrophic community and, thereby, provide a better characterization of the mat's potential for $\mathrm{N}_{2}$ fixation. Amplification results indicated that the isolates obtained in this study were likely genetically similar to diazotrophs at the microbial mat sites and were indicative of the natural heterotrophic community diversity.

The finding that similar $\mathrm{N}_{2}$-fixing organisms were present at the 3 sites, as evidenced by both sequence data and internal primer amplification, suggests that heterotrophic diazotrophs may, at least in part, be responsible for the high rates of $\mathrm{N}_{2}$ fixation observed in intertidal microbial mats. Numerous isolates appear to be novel $\mathrm{N}_{2}$-fixing organisms on the basis of nifH gene sequence comparisons, suggesting that the marine diazotrophic community is far more complex than previously thought (e.g. Guerinot \& Colwell 1985, Kirshtein et al. 1993, Zehr et al. 1995). The heterotrophic bacteria isolated in this study demonstrated different growth preferences, indicating a great deal of metabolic diversity capable of exploiting the diverse habitats and steep environmental gradients characterizing microbial mats

Acknowledgements. We thank T F. Steppe, J. P. Zehr, and J. Diehl for technical assistance and discussions. This work was supported by grants from the National Science Foundation, projects DEB 9408471 and OCE 9415985.

\section{LITERATURE CITED}

Bebout B, Paerl HW, Crocker KM, Prufert LE (1987) Diel interactions of oxygenic photosynthesis and $\mathrm{N}_{2}$ fixation (acetylene reduction) in a marine microbial mat community. Appl Environ Microbiol 53:2353-2362

Bebout BM, Fitzpatrick MW, Paerl HW (1993) Identification of the sources of energy for nitrogen fixation and physiological characterization of nitrogen-fixing members of a marine microbial mat community. Appl Environ Microbiol 59:1495-1503

Ben-Porath J, Zehr JP (1994) Detection and characterization of cyanobacterial nifH genes. Appl Environ Microbiol 60: $880-887$

Bothe $H$ (1982) Nitrogen fixation. In: Carr NG, Whitton BA (eds) The biology of cyanobacteria. Blackwell Scientific Publications, Oxford, p 87-104

Capone DG, Zehr JP, Paerl HW, Bergman B, Carpenter EJ (1997) Trichodesmium, a globally significant marine cyanobacterium. Science 276:1221-1229

Carpenter EJ, Capone DG (1983) Nitrogen in the marine environment. Academic Press, New York

Cohen Y, Castenholtz RW, Halvorson HO (1984) Microbial mats: stromatolites, AR Liss, New York

Currin CA, Paerl HW, Suba GK, Alberte RS (1990) Immunofluorescence detection and characterization of $\mathrm{N}_{2}$-fixing microorganisms from aquatic environments. Limnol Oceanogr 35:59-71

Dawson MP, Humphrey BA, Marshall KC (1981) Adhesion: a tactic in the survival strategy of a marine Vibrio during starvation. Curr Microbiol 6:195-199

Dugdale RC, Menzel DW, Ryther JH (1961) Nitrogen fixation in the Sargasso Sea. Deep-Sea Res 7:298-300

Felsenstein J (1995) PHYLIP (Phylogeny Inference Package) University of Washington, Seattle, WA

Fogg GE (1982) Marine plankton. In: Carr NG, Whitton BA (eds) The biology of cyanobacteria. Blackwell Scientific Publications, Oxford, p 491-513

GCG Seglab Software (1986) Seqlab guide: the graphical user interface of the Wisconsin program. Genetics Computer Group, Madison, WI

Guerinot ML, Colwell RR (1985) Enumeration, isolation, and characterization of $\mathrm{N}_{2}$-fixing bacteria from seawater. Appl Environ Microbiol 50:350-355

Guerinot ML, West PA, Lee JV, Colwell RR (1982) Vibrio diazotrophicus sp. nov., a marine nitrogen-fixing bacterium Int J Syst Bacteriol 32:350-357

Hardy RWF, Holsten RD, Jackson EK, Burns RC (1968) The acetylene-ethylene assay for $\mathrm{N}_{2}$ fixation: laboratory and field evaluation. Plant Physiol 43:1185-1207

Hennecke H, Kaluza K, Thony B, Fuhrmann M, Ludwig W, Stackebrandt E (1985) Concurrent evolution of nitrogenase genes and 16S rRNA in Rhizobium species and other nitrogen fixing bacteria. Arch Microbiol 142: $342-348$ 
Holt JG, Krieg NR, Sneath PHA, Staley JT, Williams ST (1994) Bergey's manual of determinative bacteriology, 9th edn. Williams and Wilkins, Baltimore, MD

Jackson CR, Harper JP, Willoughby D, Roden EE, Churchill PF (1997) A simple, efficient method for the separation of humic substances and DNA from environmental samples. Appl Environ Microbiol 63:4993-4995

Joye SB, Paerl HW (1994) Nitrogen cycling in microbial mats rates and patterns of denitrification and nitrogen fixation Mar Biol 119:285-295

Kawai A, Sugahara I (1971) Microbiological studies on nitrogen in aquatic environments. II. On the nitrogen fixing bacteria in offshore regions. Bull Jpn Soc Sci Fish 37:981-985

Kirshtein JD, Zehr JP, Paerl HW (1993) Determination of $\mathrm{N}_{2}$ fixation potential in the marine environment: application of the polymerase chain reaction. Mar Ecol Prog Ser 95:305-309

Krieg NR, Hoffman PS (1986) Microaerophily and oxygen toxicity. Annu Rev Microbiol 40:107-130

Lovell CR, Piceno Y (1994) Purification of DNA from estuarine sediments. J Microbiol Methods 20:161-174

Maruyama Y, Taga N, Matsuda O (1970) Distribution of nitrogen-fixing bacteria in the central Pacific Ocean. J Oceanogr Soc Jpn 26:360-366

Paerl HW, Carlton RG (1988) Control of nitrogen fixation by oxygen depletion in surface-associated microzones Nature 332:260-262

Paerl HW, Pinckney JL (1996) A mini-review of microbial consortia: their roles in aquatic production and biogeochemical cycling. Microb Ecol 31:225-247

Paerl HW, Prufert LE (1987) Oxygen-poor microzones as potential sites of microbial $\mathrm{N}_{2}$ fixation in nitrogendepleted aerobic marine waters. Appl Environ Microbiol 53:1078-1087

Pinckney J, Paerl HW, Fitzpatrick M (1995) Impacts of seasonality and nutrients on microbial mat community structure and function. Mar Ecol Prog Ser 123:207-216

Paerl HW, Bebout BM, Prufert LE (1989) Naturally occurring patterns of oxygenic photosynthesis and $\mathrm{N}_{2}$ fixation in a marine microbial mat: physiological and ecological ramifications. In: Cohen Y, Rosenberg E (eds) Microbial mats: physiological ecology of benthic microbial communities. American Society for Microbiology, Washington, DC, p 326-341

Paerl HW, Fitzpatrick M, Bebout BM (1996) Seasonal nitrogen fixation dynamics in a marine microbial mat: potential roles of cyanobacteria and microheterotrophs. Limnol Oceanogr 41:419-427

Postgate FRS (1982) The fundamentals of nitrogen fixation. Cambridge University Press, Cambridge

Editorial responsibility: Jed Fuhrman,

Los Angeles, California, USA
Shieh WY, Simidu U, Maruyama Y (1989) Enumeration and characterization of nitrogen-fixing bacteria in an eelgrass (Zostera marina) bed. Microb Ecol 18:249-259

Steppe TF, Olson JB, Paerl HW, Litaker RW, Belnap J (1996) Consortial $\mathrm{N}_{2}$ fixation: a strategy for meeting nitrogen requirements of marine and terrestrial cyanobacterial mats. FEMS Microbiol Ecol 21:149-156

Swofford DL (1991) PAUP: phylogenetic analysis using parsimony. Illinois Natural History Survey, Champaign, IL

Tibbles BJ, Rawlings DE (1994) Characterization of nitrogenfixing bacteria from a temperate saltmarsh lagoon, including isolates that produce ethane from acetylene. Microb Ecol 27:65-80

Tsai YL, Olson BH (1992) Rapid method for separation of bacterial DNA from humic substances in sediments for polymerase chain reaction. Appl Environ Microbiol 58: $2292-2295$

Ueda T, Suga Y, Yahiro N, Matsuguchi T (1995) Remarkable $\mathrm{N}_{2}$-fixing bacterial diversity detected in rice roots by molecular evolutionary analysis of nifH gene sequences. J Bacteriol 177:1414-1417

Urdaci MC, Stal LJ, Marchand M (1988) Occurrence of nitrogen fixation among Vibrio spp. Arch Microbiol 150 $224-229$

Valiela I, Teal JM (1979) The nitrogen budget of a salt marsh ecosystem. Nature 280:652-656

Woese CR (1987) Bacterial evolution. Microbiol Rev 51 $255-271$

Woese CR, Weisburg WG, Hahn CM, Paster BJ, Zablen LB, Lewis BJ, Macke TJ, Lugwig W, Stackebrandt E (1985) The phylogeny of purple bacteria: the gamma subdivision. Syst Appl Microbiol 6:25-33

Wynn-Williams PD, Rhodes ME (1974) Nitrogen fixation in seawater. J Appl Bacteriol 37:203-216

Young JPW (1992) Phylogenetic classification of nitrogen-fixing organisms In: Stacey GB, Evans HJ, Burris RH (eds) Biological nitrogen fixation. Chapman and Hall, London, p 43-86

Zehr JP, McReynolds LA (1989) Use of degenerate oligonucleotides for amplification of the nifH gene from the marine cyanobacterium Trichodesmium thiebauti. Appl Environ Microbiol 55:2522-2526

Zehr JP, Mellon M, Braun S, Litaker W, Steppe T, Paerl HW (1995) Diversity of heterotrophic nitrogen fixation genes in a marine cyanobacterial mat. Appl Environ Microbiol 61 . $2527-2532$

Zhou J, Bruns MA, Tiedje JM (1996) DNA recovery from soils of diverse composition. Appl Environ Microbiol 62: $316-322$

Submitted: June 15, 1998; Accepted: March 17, 1999 Proofs received from author(s): August 16, 1999 